\title{
PERUBAHAN TEKANAN DARAH PADA LANSIA YANG MELAKUKAN SENAM PROLANIS DI PUSKESMAS TAMALANREA KOTA MAKASSAR
}

\section{BLOOD PRESSURE CHANGES IN LANS WHO DO PROLANISM IN TAMALANREA PUSKESMAS TAMALANREA CITY OF MAKASSAR}

\author{
Noyumala $^{1}$, Sri Darmawan ${ }^{2}$, Sriwahyuni $^{3}$, Adalina Seltit $^{4}$ \\ ${ }^{1}$ Program Studi Ners, STIKes Gunung Sari, Makassar \\ ${ }^{2}$ Program Studi DIII Keperawatan, STIKes Nani Hasanuddin Makassar \\ ${ }^{3}$ Program Studi Ners, STIKes Nani Hasanuddin Makassar \\ ${ }^{4}$ Program Studi S1 Keperawatan, STIKes Nani Hasanuddin Makassar \\ Email: ${ }^{1}$ noyumala@gmail.com, ${ }^{2}$ sridarmawan58@gmail.com, ${ }^{4}$ adalinaseltit@gmail.com \\ *Corresponding author: ${ }^{3}$ Sriwahyunicallista@gmail.com
}

\begin{abstract}
ABSTRAK
Latar Belakang: Penyakit tekanan darah tinggi atau dikenal dengan hipertensi merupakan salah satu penyakit yang paling sering dirasakan oleh masyarakat, namun 95 persen tanda dan gejala tidak jelas tingginya prevalensi penderita hipertensi di seluruh dunia meningkat terutama Negara yang sedang berkembang termasuk Indonesia. Olahraga bagi penderita hipertensi merupakan salah satu olahraga yang dapat mengendurkan pembuluh darah. melakukan aktivitas atau olahraga baik dalam rumah atau diluar rumah secara terus menerus dengan waktu tertentu dapat terjadi perubahan tekanan darah dimana hal ini dilakukan dalam waktu lama dapat membuat pembuluh darah menjadi elastis karena pembuluh darah bias lebih rileks yang menyebabkan pelebaran pembuluh darah sehingga tekanan darah bisa menurun. Tujuan: Untuk mengetahui perubahan tekanan darah pada lansia yang melakukan senam prolanis. Populasi dalam penelitian ini adalah semua lansia penderita hipertensi yang rutin mengikuti senam prolanis setiap minggu yaitu sebanyak 11 orang sehingga menggunakan total sampling. Metode: quasi eksperimen dengan rancangan rangkaian waktu (Time Series Design). Desain ini digunakan untuk observasi yang dilakukan baik itu sebelum dan sebelum perlakuan. Hasil: berdasarkan observasi yang dilakukan pada pertemuan I, III, V diperoleh hasil perbandingan tekanan darah sebelum latihan prolanis $p=0,002<a=0,05$ sedangkan rasio tekanan darah diastolik setelah latihan prolanis $p=0,002<a=0,05$. Kesimpulan: Ada perubahan tekanan darah sistolik dan hipertensi setelah dan sebelum melakukan senam prolanis. Diharapkan penderita hipertensi dapat berolahraga secara teratur yang diharapkan dapat memberikan maaf untuk mengubah tekanan darah menjadi lebih rendah, meningkatkan kebugaran dan meningkatkan metabolisme tubuh yang dapat mengontrol tekanan darah.
\end{abstract}

Kata kunci: Senam Prolanis, Tekanan Darah, Lansia.

\begin{abstract}
Background: High blood pressure disease or known as hypertension is one of the diseases that is most often felt by the community but 95 percent of the signs and symptoms are not clear. The high prevalence of hypertension sufferers throughout the world is increasing, especially developing countries including Indonesia. Exercise for people with hypertension is one of the sports that can relax blood vessels. Doing activities or sports both at home or outside the house continuously for a certain time can cause changes in blood pressure which if this is done for a long time can make blood vessels elastic because blood vessels can relax more which causes dilation of blood vessels so that changes blood pressure can decrease. Objective: To determine changes in blood pressure in the elderly who do prolanis exercise. The population in this study were all elderly people with hypertension who routinely participated in prolanis exercise every week, as many as 11 people, so that using total sampling. Method: quasi experiment with time series design (Time Series Design). This design was used for repeated observations, both before and after treatment. Results: based on observations made at meetings I, III, V, the results of the comparison of systolic blood pressure before prolanis exercise were $p=0.002<a=0.05$ while the pressure ratio was diastolic blood after exercise prolanis $p=0.002<a=0.05$. Conclusion: There are changes in systolic blood pressure and hypertension after and before doing prolanis exercise. It is expected that people with
\end{abstract}


hypertension can exercise regularly which is expected to provide forgiveness to lower blood pressure, improve fitness and increase body metabolism which can control blood pressure.

Keywords: Prolanic Gymnastics, Blood Pressure, Elderly.

\section{PENDAHULUAN}

Penyakit tekanan darah tinggi atau dikenal dengan hipertensi merupakan salah satu penyakit yang paling sering dirasakan oleh masyarakat namun 95 persen tanda dan gejala tidak jelas, beberapa penyebab yang biasa menjadi multifaktor yang jika saat terjadi atau dialami hipertensi oleh sesorang namun tidak dilakukan penagulangan atau penanganan yang segera dengan baik maka bila tidak segera diatasi, "the silent killer" ini cenderung menimbulkan komplikasi pada berbagai sasaran, yaitu jantung, pembuluh darah otak, pembuluh darah perifer, ginjal dan retina. Melakukan aktivitas atau olahraga baik dalam rumah atau diluar rumah secara terus menerus dengan waktu tertentu dapat terjadi perubahan tekanan darah dimana jika hal ini dilakukan dalam waktu lama dapat membuat pembuluh darah menjadi elastis karena pembuluh darah bias lebih rileks yang menyebabkan pelebaran pembuluh darah sehingga merubah tekanan darah bisa menurun. Hipertensi (HTN) tidak hanya dikenal sebagai faktor risiko berkontribusi terhadap penyakit kardiovaskular (CVD) tetapi juga masalah kesehatan di masyarakat, Populasi global yang saat ini menderita HTN diperkirakan lebih dari 1,5 miliar orang Sekitar 7,6 juta kematian dini disebabkan HTN, yaitu sekitar $13,5 \%$. Hipertensi sistolik terisolasi (ISH) ditentukan sebagai tekanan darah $(\mathrm{BP})=140 /<90 \mathrm{mmHg}$ sering terjadi pada manula, selain itu juga dapat ditemukan pada yang muda. Resiko faktor HTN diketahui usia, kebugaran fisik rendah, penggunaan tembakau, pola makan yang tidak sehat, dan konsumsi garam yang tinggi (Bui Van et al., 2018).

Tekanan darah terjadi akibat adanya proses jantung memompa darah melalui dinidng arteri. Pada manusia, darah dipompa melalui dua sistem sirkulasi terpisah dalam jantung yaitu sirkulasi pulmonal dan sirkulasi sistemik. Darah dari ventrikel kanan dipompa keluar jantung menuju ke paru-paru untuk pertukaran karbondioksida dengan oksigen. Darahyang sudah kaya akan oksigen dipompa masuk ke serambi kiri melalui vena pulmonalis, dan selanjutnya dipompa ke bilik kiri akan dipasok ke seluruh tubuh (Amiruddin, 2015). Tekanan dapat berubah karena beberapa faktor seperti usia pada usia dewasa $120 / 80 \mathrm{mmHg}$ dianggap sebagai nilai normal, dan pada anak lebih rendah dari $120 / 80 \mathrm{mmHg}$ batas normal, selain usia aktivitas yang tinggi pola maka juga merupakan bagiandari terjadinya perubahan tekanan darah seseorang (Amiruddin, 2015). Berdasarkan hasil survei dari prevalensi hipertensi hingga tahun 2018, dikatehui bahwa $=18$ tahun yang didiagnosis hipertensi oleh dokter adalah 34,1\%. Data dari organisasi kesehatan dunia pada tahun 2015 menunjukkan bahwa sekitar 1.13 miliar orang didunia menderita hipertensi artinya 1 dari 3 orang di dunia didiagnosis menderita hipertensi (Ernawati, 2020).

Hipertensi secara umum dapat didefinisikan sebagai tekanan sistolik lebih dari $140 \mathrm{mmHg}$ dan tekanan diastolik lebih dari $90 \mathrm{mmHg}$. Dalam kehidupan sehari- hari perubahan tekanan darah manusia bisa menjadi problem jika suplai darah kejaringan berkurang maka akan menyebakan terjadinya ketegangan pada jantung dan otak (Manuntung, 2018).

Berdasarkan World Health Organization (WHO), di seluruh dunia sekitar 972 juta orang atau $26,4 \%$ didunia akan menglami hipertensi yang berisiko akan terjadi peningkatan yang lebih banyak dan mencapai angka menjadi $29,2 \%$ di perkirakan pada tahun 2025 (Yonata, 2016). Beradsarkan Riset Kesehatan Dasar tahun 2013 diperkirakan prevalensi $45,9 \%$ yang akan banyak terjadi pada usia 55-64 tahun, dan $57,6 \%$ sampai $63,8 \%$ pada usia kemungkinan akan terjadi pada usia 75 tahun (Infodatin Kemenkes RI, 2016) dalam (Zaenurrohmah \& Rachmayanti, 2017).

Berdasarkan Profil Kesehatan Kota Makassar data dari Bidang Bina P2PL Dinas Kesehatan Kota Makassar tahun 2015 terdapat kasus hipertensi sebanyak 11.596 dengan rincian jenis kelamin yaitu laki-laki sebanyak 4.277 kasus dan perempuan sebanyak 7.319 kasus (Dinkes Makassar, 2015). Di Puskesmas Tamalanrea Kota Makassar didapatkan jumlah kasus hipertensi 
dengan program senam prolanis pada tahun 2017 sampai 2018 mengalami peningkatan. Sedangkan 4 bulan terakhir sebanyak 70 orang dengan jumlah penderita hipertensi yang tidak rutin melakukan senam prolanis satu kali dalam seminggu setiap hari sabtu selama 1 bulan terakhir (April) sebanyak 59 orang $(84,29 \%)$ dan yang rutin melakukan senam prolanis sebanyak 11 orang $(15,71 \%)$ (Rekam Medik Puskesmas Tamalanrea Kota Makassar, 2019). Adapun tujuan dari penelitian ini yaitu untuk mengetahui perubahan tekanan darah pada lansia yang melakukan senam prolanis.

\section{METODE}

Desain penelitian yang digunakan dalam penelitian ini adalah jenis penelitian yang disebut penelitian eksperimental semu atau quasi experiment dengan rancangan rangkaian waktu (Time Series Desain). Populasi dalam penelitian ini adalah semua lansia penderita hipertensi yang rutin

\section{Analisis Bivariat}

Tabel 2. Perbandingan Tekanan Darah Sistole dan Diastole Lansia Penderita Hipertensi Sebelum dan Sesudah Senam Prolanis pada Minggu I, III dan V di Puskesmas Tamalanrea Kota

\begin{tabular}{|c|c|c|c|}
\hline $\begin{array}{l}\text { Minggu I } \\
\text { Median } \\
(\text { Min-Max) }\end{array}$ & $\begin{array}{l}\text { Minggu III } \\
\text { Median } \\
(\text { Min-Max) }\end{array}$ & $\begin{array}{l}\text { Minggu V } \\
\text { Median } \\
\text { (Min-Max) }\end{array}$ & Nilai p \\
\hline Sebelum senam & & 1 & \\
\hline TD sistole (mmHg) & $150(130-170)$ & $140(120-150)$ & 0.000 \\
\hline TD diastole $(\mathrm{mmHg})$ & $100(80-110)$ & $80(80-100)$ & 0.002 \\
\hline Sesudah senam & & & \\
\hline TD sistole $(\mathrm{mmHg})$ & $140(120-150)$ & $130(110-140)$ & 0.000 \\
\hline TD diastole $(\mathrm{mmHg})$ & $80(70-100)$ & $80(60-100)$ & 0.022 \\
\hline $\begin{array}{l}\text { Berdasarkan tabel } 2 \text { menunjukkan } \\
\text { hwa perbandingan tekanan darah sistole } \\
\text { elum senam prolanis minggu I median } \\
0 \mathrm{mmHg} \text {, minggu III median } 150 \mathrm{mmHg} \\
\mathrm{n} \text { minggu } \mathrm{V} \text { median } 140 \mathrm{mmHg} \text {. Data } \\
\text { distribusi tidak normal dengan } \\
\text { nggunakan uji Friedman didapatkan nilai } \\
0.000<\mathrm{a}=0.05 \text { yang berarti Ha di terima } \\
\text { hwa ada perbedaan tekanan darah systole } \\
\text { sia penderita hipertensi sebelum senam } \\
\text { da minggu I, III dan V, sedangkan } \\
\text { tbandingan tekanan darah systole sebelum } \\
\text { lam prolanis pada minggu I median } 110 \\
\text { nHg, minggu III median } 100 \text { mmHg dan } \\
\text { nggu V median } 80 \text { mmHg. Berdasarkan uji } \\
\text { iedman didapatkan nilai p=0.002 }<\text { a = } \\
55 \text { yang berarti Ha di terima bahwa ada } \\
\text { bedaan tekanan darah sistole dan diastole }\end{array}$ & \multicolumn{3}{|c|}{$\begin{array}{l}\text { lansia penderita hipertensi sebelum senam } \\
\text { pada minggu I, III dan V. } \\
\text { Perbandingan tekanan darah sistole } \\
\text { sesudah senam prolanis minggu I median } 150 \\
\text { mmHg, minggu III median } 140 \mathrm{mmHg} \text { dan } \\
\text { minggu V median } 130 \mathrm{mmHg} \text {. Berdasarkan } \\
\text { uji Friedman didapatkan nilai } \mathrm{p}=0.000<a= \\
0.05 \text { yang berarti Ha di terima bahwa ada } \\
\text { perbedaan tekanan darah sistole lansia } \\
\text { penderita hipertensi sesudah senam pada } \\
\text { minggu I, III dan V, sedangkan perbandingan } \\
\text { tekanan darah diastole sesudah senam } \\
\text { prolanis pada minggu I, III, V median } 80 \\
\text { mmHg. Berdasarkan uji Friedman didapatkan } \\
\text { nilai p = } 0.002<a=0.05 \text { yang berarti Ha di } \\
\text { terima bahwa ada perbedaan tekanan darah } \\
\text { diastole lansia penderita hipertensi sesudah } \\
\text { senam pada minggu I, III dan V. }\end{array}$} \\
\hline
\end{tabular}

mengikuti senam prolanis satu kali dalam setiap minggu yaitu sebanyak 11 orang sehingga menggunakan total sampling.

\section{HASIL DAN PEMBAHASAN}

\subsection{Hasil}

\section{Analisis Univariat}

Tabel 1. Distribusi Responden Berdasarkan Umur, Jenis Kelamin dan Pendidikan Lansia Penderita Hipertensi

\begin{tabular}{ccc}
\hline Distribusi Responden & $\begin{array}{c}\text { Frekuensi } \\
(\mathbf{n})\end{array}$ & $\begin{array}{c}\text { Persentase } \\
(\%)\end{array}$ \\
\hline Umur & & \\
\hline 56 Tahun & 5 & 40.0 \\
\hline$>56$ Tahun & 6 & 60.0 \\
\hline Jenis Kelamin & & \\
\hline Laki - Laki & 4 & 36.4 \\
\hline Perempuan & 7 & 63.7 \\
\hline Pendidikan & & \\
\hline SD & 1 & 9.1 \\
\hline SMP & 1 & 9.1 \\
\hline SMA & 5 & 45.4 \\
\hline S1 & 3 & 27.3 \\
\hline S3 & 1 & 9.1 \\
\hline & &
\end{tabular}




\subsection{Pembahasan}

Penelitian ini sesuai dengan beberapa penelitian sebelumnya dilakukan oleh (Lumempouw et al., 2016), dengan judul "Pengaruh Senam Prolanis Terhadap Penyandang Hipertensi" menunjukkan bahwa dari 25 responden, jumlah responden perempuan $(76 \%)$ lebih banyak dari laki-laki (24\%) karena pada usia 65 saat memasuki masa menopause tekanan darah wanita semakin meningkat disebakan karena perubahan hormonal (Zulaikha, Kasjono, \& Wijayanti, 2016).

Begitupula penelitian yang dilakukan oleh (Ibrahim HS \& Syafei, 2013), dengan judul "Perbedaan Nilai Tekanan Darah Lansia dengan tekanan darah tinggi sebelum dan setelah melaksanakan Olahraga Senam pada Lansia" sebagian besar hipertensi terjadi pada umur lebih dari 55 tahun, walaupun sebelum umur 55 tahun tekanan darah lebih tinggi pada laki-laki akan tetapi setelah berumur 60 tahun akan terjadi peningkatan tekanan darah yang terjadi pada wanita sehingga beresiko terkenan tekanan darah tinggi. Seiring bertambanya usia maka resiko terkena tekanan darah tinggi lebih tinggi karena adanya penebalan pada dinding arteri mengakibatkan adanya penumpukan zat kolagen pada bagian lapisan otot terjadi perubahan pada pembuluh darah yaitu pembuluh darah menjadi kaku, elastisitas berkurang dan berangsur-angsur menyempit menyebabkan terjadinya peningkatan tekanan darah (Tim Bumi Medika, 2017).

Berdasarkan hasil uji Wilcoxon pada minggu I didapatkan nilai $\mathrm{p}=0.083>\mathrm{a}=$ 0.05 maka tidak ada perbedaan tekanan darah sistole sebelum dan sesudah senam prolanis pada lansia penderita hipertensi, sedangakan pada tekanan darah diastole didapatkan nilai $\mathrm{p}=-0.005<\mathrm{a}=0.05$ maka ada perubahan tekanan darah diastole pada lansia penderita hipertensi sebelum dan setelah senam melakukan prolanis.

Penelitian ini sejalan dengan penelitian yang dilakukan oleh (Sunkudon, Palandeng, \& Kallo, 2015), dengan judul "Pengaruh Senam Lansia Terhadap Stabilitas Tekanan Darah pada grup lanjut usia GMIM Anugerah di Desa Tumaratas 2 Kecamatan Langowan Barat Kabupaten Minahasa" dai hasil nalisi menunjukkan bahwa pada pelaksanaan pertama diperoleh nilai nilai $\mathrm{p}=0.083>\mathrm{a}=$ 0.05 menunjukkan tidak ada perubahan tekanan darah sistole pre dan post senam lansia, sedangkan pada tekanan darah diastole didapatkan nilai $\mathrm{p}=0.000<\mathrm{a}=0.05$ yang artinya ada perubahan peningkatan tekanan darah diastole pre dan post senam lansia pada kelompok lansia GMIM Anugerah di Desa Tumaratas 2 Kecamatan Langowan Barat Kabupaten Minahasa.

Dalam melakukan aktivitas seperti olahragasebaiknya dilakukan secara kontinyu untuk mencapai intensitas yang adekuat. Atau batas minimal tertentu agar dapat menghasilkan manfaat, khususnya dapat meningkatkan peredaran darah, menguatkan otot jantung, pernapasan dan lain-lain yang diselenggarakan minimal 2 kali per minggu, apabila intensitasnya minimal tidak adekuat, maka dampak olahraga kesehatan menjadi sangat minim atau bahkan tidak ada (Giriwijoyo \& Sidik, 2012).

Berdasarkan hasil uji Wilcoxon pada minggu III tekanan darah sistole mengalami penurunan, yaitu $10 \mathrm{mmHg}$. Diperoleh nilai $\mathrm{p}=0.002<\mathrm{a}=0.05$ maka ada perbedaan tekanan darah sistole sebelum dan sesudah senam prolanis pada lansia penderita hipertensi, sedangkan pada tekanan darah diastole didapatkan nilai nilai $\mathrm{p}=0.012<\mathrm{a}=$ 0.05 maka diperoleh adanya perbedaan tekanan darah diastole pada lansia penderita hipertensi pre dan post senam prolanis. Penelitian ini sesuai dengan yang telah dilaksanakan oleh Zulaikha et al., (2016), dengan judul "Efektivitas Senam Lansia terhadap Penurunan Tekanan Darah pada Lansia Hipertensi di Wilayah Kerja Puskesmas Bulu Kabupaten Sukoharjo" dari hasil analisis diperoleh bahwa rata-rata tekanan darah sistole pada grup percobaan ke 2 setelah dilakukan senam lansia dengan intensitas sebanyak 3 kali dalam seminggu dapat terjadi penurunan, yaitu dari 174.44 mmHg menjadi $154,44 \mathrm{mmHg}$ dengan selisih $20 \mathrm{mmHg}$, adapun hasil analisis dari penelitian sebelumnya oleh (Sunkudon et al., 2015), dengan judul "Pengaruh Senam Lansia Terhadap Stabilitas Tekanan Darah pada grup Lansia GMIM Anugerah di Desa Tumaratas 2 Kecamatan Langowan Barat Kabupaten Minahasa" dari hasil analisis ditemukan pada pertemuan III diperoleh nilai $\mathrm{p}=0.013<\mathrm{a}=$ 0.05 sehingga diinteprestasikan adanya perbedaan tekanan darah diastole pre dan post senam lansia pada grup lansia GMIM Anugerah di Desa Tumaratas 2 Kecamatan 
Langowan Barat Kabupaten Minahasa. Jika seseorang sering dan rutin melaksanakan aktivitas seperti senam maka akan memacu kerja jantung untuk bekerja lebih optimal yang dapat meningkatkan kebutuhan energi pada sel dan organ tubuh yang lain yang dapat meningktkan aliaran balik pada vena untuk meningkatkan curah jantung sehingga tekanan darah ke arteripun meningkat sehingga dapat mengurangi aktivitas pernafasan pada otot rangka dan penurunan pada saraf simpatis yang memungkinkan terjadinya percepatan denyut jantung menurun karena terjadi vasodilatasi arteri vena sehingga terjadi resistensi perifer total maka terjadi penurunan tekanan darah hal ini yang menyebabkan terjadinya perubahan tekanan drah pada lansia saat melakukan olahraga atau aktivitas seperti senam lansia karena berkurangya hambatan dalam pembuluh kapiler agar bisa lebih mudah mengalirkan darah sebelum dan setelah melaksanakan olahraga (Herwawan \& Rosyid, 2017).

Berdasarkan hasil uji Wilcoxon pada minggu $\mathrm{V}$ tekanan darah sistole didapatkan nilai $\mathrm{p}=0.014<\mathrm{a}=0.05$ maka ada perbedaan tekanan darah sistole sebelum dan sesudah senam prolanis pada lansia penderita hipertensi, sedangakan pada tekanan darah diastole didapatkan nilai $\mathrm{p}=0.018<\mathrm{a}=0.05$ maka ada perbedaan tekanan darah diastole pada lansia penderita hipertensi sebelum dan sesudah senam prolanis. Penelitian ini sejalan dengan penelitian yang dilakukan oleh (Sidio, 2019), dengan judul "Pengaruh Senam Prolanis Terhadap Tekanan Darah Pasien Hipertensi di Puskesmas Purwodiningratan Kota Surakarta" hasil penelitian menunjukkan bahwa pada minggu ke-5 tekanan darah sistole sebelum dan sesudah senam didapatkan nilai $\mathrm{p}=0.002<\mathrm{a}=0.05$, sedangkan tekanan darah diastole didapatkan nilai $\mathrm{p}=0.001<\mathrm{a}=0.05$ maka ada pengaruh senam prolanis terhadap tekanan darah pasien hipertensi di puskesmas purwodiningratan kota Surakarta. (Menurut Kemenkes RI, 2006) olahraga yang teratur dapat membantu menurunkan tekanan darah, menambah kebugaran dan memperbaiki metabolisme tubuh yang dapat mengontrol tekanan darah. Aktivitas yang tinggi seperti berolahraga dapat mengubah system sirkulasi dalam pernafasan secara bersamaan sebagai hasil dari respon yang disebut hemostatic. Salah satu kegiatan fisik yang baik dilakukan pada pasien dengan hipertensi adalah senam aerobic seperti melakukan jalan cepat atau brisk walking dimana jika dilakukan secara kontinyu makan dapat mengubah sistolik maupun diastolik pada pasien hipertensi (Rahmawati \& Aizza, 2018).

Berdasarkan uji Friedman pada minggu I, III dan V tekanan darah sistole lansia penderita hipertensi sebelum senam prolanis didapatkan nilai $\mathrm{p}=0.000<\mathrm{a}=0.05$, sedangkan tekanan darah diastole lansia penderita hipertensi pada minggu I, III dan V didapatkan nilai $\mathrm{p}=0.002<\mathrm{a}=0.05$ maka ada perbedaan tekanan darah sistole dan diastole lansia penderita hipertensi sebelum senam pada minggu I, III dan V. Pada minggu I, III dan V tekanan darah sistole lansia penderita hipertensi sesudah senam prolanis didapatkan nilai $\mathrm{p}=0.022<\mathrm{a}=$ 0.05 , sedangkan tekanan darah diastole lansia penderita hipertensi pada minggu I, III dan V didapatkan nilai $\mathrm{p}<\mathrm{a}$ maka ada perbedaan tekanan darah sistole dan diastole sesudah senam prolanis pada minggu I, III dan V. Hal ini sesuai dengan penelitian yang dilakukan oleh (Peter Kokkinos \& Myers, 2010), dengan judul "Exercise and physical activity: Clinical outcomes and applications. Journal Circulation" yaitu melakukan senam aerobik dalam waktu yang singkat tetapi secara terus menerus juga dapat menurunkan terjadinya perubahan tekanan darah adapun penelitian lain mengatakan bahwa kegiatan dengan intensitas lebih tinggi dengan cara yang efektif dan efisien dapat mengubah tekanan darah systole dan siastole (Santana, Moreira, \& Asano, 2013). Perubahan tekanan darah baik sistole maupun diastole sesudah senam prolanis sesuai dengan teori yang menyatakan bahwa olahraga merupakan salah satu pengobatan nonfarmakologis pada pasien dengan hipertensi. Efek dari olahraga seperti senam prolanis yang dapat dilakukan secara kontinyu dapat mengubah tekanan darah lebih lancar sehingga terjadi perubahan tekanan darah (Collier et al., 2008).

\section{KESIMPULAN}

Dari uraian di atas dan tinjauan teoritis peneliti berasumsi bahwa ada pengaruh senam prolanis terhadap tekanan darah pada lansia penderita hipertensi rutin dalam mengikuti senam prolanis dan perlu memperhatikan dan 
menghindari beberapa hal yang dapat memicu terjadinya hipertensi.

\section{REFERENCES}

Bui Van, N., Pham Van, Q., Vo Hoang, L., Bui Van, T., Nguyen Hoang, N., Do Nam, K., \& Chu, D. T. (2018). Prevalence and Risk Factors of Hypertension in Two Communes in the Vietnam Northern Mountainous, 2017. BioMed Research International, 2018. https://doi.org/10.1155/2018/7814195.

Collier, S. R., Kanaley, J. A., Jr, R. C., Frechette, V., Tobin, M. M., \& Hall, A. K. (2008). Effect of 4 weeks of aerobic or resistance exercise training on arterial stiffness, blood flow and blood pressure in pre- and stage-1 hypertensives. Journal of Human Hypertension, (22), 678-686.

https://doi.org/10.1038/jhh.2008.36.

Dinkes Makassar. (2015). Profil Kesehatan Kota Makassar 2015. Makassar.

Giriwijoyo, S., \& Sidik, Z. (2012). Ilmu Faal Olahraga (Fisiologi Olahraga). Bandung: PT. Remaja Rosdakarya.

Herwawan, T., \& Rosyid, F. N. (2017). Pengaruh Senam Hipertensi Lanisa Terhadap Penurunan Tekanan Darah Lansia Dengan Hipertensi Di Panti Werda Darma Bhakti Kelurahan Panjang Surakarta. Jurnal Kesehatan, 10(1), 2631.

https://doi.org/10.13040/IJPSR.09758232.6(2).688-91.

Ibrahim HS, \& Syafei, Z. (2013). Perbedaan Nilai Tekanan Darah Lansia dengan Hipertensi Sebelum dan Sesudah Olahraga Senam pada Lansia. Jurnal Ilmu Keperawatan, 1(1).

Kemenkes RI. (2006). Cegahlah Hipertensi. Jakarta: Kementrian Kesehatan Republik Indonesia.

Kokkinos, P., \& Myers, J. (2010). Exercise and physical activity: Clinical outcomes and applications. American Journal of Hypertension,

(122). https://doi.org/https://doi.org/10.1161/CI
RCULATIONAHA.110.948349.

Lumempouw, D., Wungouw, H. I. S., \& Polii, H. (2016). Pengaruh senam Prolanis terhadap penyandang hipertensi. Jurnal E-Biomedik (eBm), $4(1)$.

Rahmawati, L., \& Aizza, N. (2018). Pengaruh Senam Prolanis Terhadap Penurunan Tekanan Darah Pada Lansia Di Desa Glagahwero Kecamatan Panti Kabupaten Jember. 24(1), 14-22. https://doi.org/10.17129/botsci.1020.

Santana, H. A. P., Moreira, S. R., \& Asano, R. Y. (2013). Exercise intensity modulates nitric oxide and blood pressure responses in hypertensive older women. Aging Clinical and Experimental Research. Springer International Publishing AG, 25(1). https://doi.org/https://doi.org/10.1007/s4 0520-013-0017-x.

Sidio, M. N. (2019). Pengaruh Senam Prolanis Terhadap Tekanan Darah Pasien Hipertensi di Puskesmas Purwodiningratan Kota Surakarta.

Sunkudon, M. C., Palandeng, H., \& Kallo, V. (2015). Pengaruh Senam Lansia Terhadap Stabilitas Tekanan Darah pada Kelompok Lansia GMIM Anugerah di Desa Tumaratas $2 \mathrm{Kec}$. Langowan Barat Kab. Minahasa. 3, 1-7.

Tim Bumi Medika. (2017). Berdamai dengan Hipertensi. Jakarta: Bumi Medika.

Zaenurrohmah, D. H., \& Rachmayanti, R. D. (2017). Hubungan Pengetahuan dan Riwayat Hipertensi dengan Tindakan Pengendalian Tekanan Darah pada Lansia. Jurnal Berkala Epidemiologi, 5(4), 157-184. https://doi.org/10.20473/jbe.v5i2.2017.1 74-184.

Zulaikha, I., Kasjono, H. Z., \& Wijayanti, A. C. (2016). Efektivitas Senam Lansia terhadap Penurunan Tekanan Darah pada Lansia Hipertensi di Wilayah Kerja Puskesmas Bulu Kabupaten Sukoharjo. 1-12. 